\title{
Histidine decarboxylases from bacteria that colonise the human respiratory tract
}

\author{
D. R. CUNDELL, J. L. DEVALIA, M. WILKS,* S. TABAQCHALI* and R. J. DAVIES $\dagger$ \\ Departments of Respiratory Medicine and *Medical Microbiology, St Bartholomew's Hospital and Medical College, \\ West Smithfield, London EC1A 7BE
}

\begin{abstract}
Summary. We investigated whether production of histamine by bacteria isolated from sputum of patients with infective lung diseases could be attributed to the presence of histidine decarboxylase (HD). Twenty gram-positive and 20 gram-negative organisms were studied for their ability to decarboxylate ${ }^{14} \mathrm{C}$-histidine in vitro over the $\mathrm{pH}$ range $4 \cdot 5-7 \cdot 5$. Of the bacteria investigated, lysates from the gram-negative species Haemophilus influenzae, $H$. parainfluenzae, Moraxella (Branhamella) catarrhalis and Pseudomonas aeruginosa liberated ${ }^{14} \mathrm{CO}_{2}$ and histamine from ${ }^{14} \mathrm{C}$-histidine in the presence of the cofactor pyridoxal phosphate. In contrast, results obtained in the absence of cofactor were similar to those of negative (lysate-free) controls suggesting that the HD enzymes of these species resembled those previously described in other gram-negative bacteria. No HD activity was detected over this $\mathrm{pH}$ range in lysates from gram-positive species. This finding correlated with earlier observations that these gram-positive organisms did not produce histamine in vitro.
\end{abstract}

\section{Introduction}

Histamine production by gram-positive and gramnegative bacteria has been reported by several authors and has been associated with food spoilage by species such as Salmonella typhimurium, Lactobacillus buchnerii and Morganella morganii. ${ }^{1}$ Although many of the bacteria that produce histamine by decarboxylation of histidine inhabit the gastrointestinal tracts of animals and man, ${ }^{2}$ recent studies have demonstrated that several gram-negative species which may be found in the respiratory tract are also capable of histamine production. ${ }^{3,4}$ These include Haemophilus parainfluenzae, $H$. influenzae and Pseudomonas aeruginosa. In contrast, none of the gram-positive bacteria isolated from similar sites investigated so far (Staphylococcus aureus, Streptococcus pneumoniae, $\alpha$-haemolytic streptococci and coagulase-negative staphylococci) have been found to produce histamine. ${ }^{4}$

Histamine production by bacteria is usually due to the presence of a functional histidine decarboxylase (HD) that converts histidine to histamine and $\mathrm{CO}_{2}$. Some other decarboxylase enzymes, notably arginine decarboxylase, can also decarboxylate small amounts of histidine ${ }^{5,6}$ HDs are widespread, occurring in both mammalian $^{7}$ and bacterial cells. ${ }^{8}$ They have been divided into two major groups-those that require pyridoxal phosphate (pyridoxal-P) as a co-enzyme and those that contain a covalently-bound pyruvoyl residue

Received 19 Feb. 1991 ; revised version accepted 3 April 1991. † Correspondence should be sent to Dr R. J. Davies. at the active site and do not require the cofactor. ${ }^{9}$ The former class of enzymes has been found only in gramnegative bacteria whereas the latter occur in grampositive organisms. ${ }^{7,8}$ However, both classes of enzyme are highly specific for histidine as substrate and metabolise this compound at similar rates. ${ }^{8}$ Several authors have demonstrated that optimal activity of bacterial HDs depends on the $\mathrm{pH}$ of the surrounding medium, with enzymes from gram-positive and gramnegative bacteria functioning optimally at $\mathrm{pH} 4.5$ and 6.5 respectively. ${ }^{5,7,8,9}$ In view of this $\mathrm{pH}$-dependency of HDs the aim of this study was to investigate whether the previously observed histamine production by certain bacterial species that may inhabit the respiratory tract was associated with a functional HD and whether activity of any enzymes present was affected by changes in $\mathrm{pH}$.

\section{Materials and methods}

\section{Isolation and disruption of bacteria}

Isolates studied (table) were found in sputum obtained from patients admitted to hospital because of acute exacerbations of chronic bronchitis, pneumonia or cystic fibrosis. Species were identified by standard microbiological techniques as described previously. ${ }^{4}$ Organisms were suspended in $2 \mathrm{ml}$ of $0.2 \mathrm{M}$ sodium phosphate buffer, $\mathrm{pH} 7 \cdot 0$, and homogenised by sonication on ice (Sonifier ${ }^{\circledR}$ cell disrupter, Branson Sonic Power Company) for $3 \mathrm{~min}$. Sonicates were examined by light microscopy to ensure that no 
Table. Bacteria studied which were isolated from sputum of patients with infective lung disease

\begin{tabular}{|c|c|}
\hline Strains studied (n) & Diagnosis of patient \\
\hline \multicolumn{2}{|l|}{ Gram-negative (20) } \\
\hline Haemophilus influenzae (5) & $\begin{array}{l}\text { Chronic bronchitis, } \\
\text { pneumonia }\end{array}$ \\
\hline $\begin{array}{l}\text { Moraxella (Branhamella) catarrhalis } \\
\text { (5) }\end{array}$ & Chronic bronchitis \\
\hline Haemophilus parainfluenzae (5) & Chronic bronchitis \\
\hline Pseudomonas aeruginosa (5) & Cystic fibrosis \\
\hline \multicolumn{2}{|l|}{ Gram-positive (20) } \\
\hline Staphylococcus aureus (5) & $\begin{array}{l}\text { Chronic bronchitis, } \\
\text { pneumonia }\end{array}$ \\
\hline Streptococcus pneumoniae (5) & Pneumonia \\
\hline$\alpha$-Haemolytic streptococci $(5)$ & Chronic bronchitis \\
\hline Coagulase-negative staphylococci (5) & Chronic bronchitis \\
\hline
\end{tabular}

intact bacteria remained. Staphylococci were not disrupted by this procedure but were lysed completely by adding lysostaphin (Sigma) $5 \mu \mathrm{g} / \mathrm{ml}$ and incubating for $15 \mathrm{~min}$ at $37^{\circ} \mathrm{C}$.

\section{Detection of $H D$ activity}

HD activity was measured by the method of Beaven et al. ${ }^{10}$ Bacterial lysates $(250 \mu \mathrm{l})$ which were standardised to be equivalent to material from c. $1 \times 10^{6}$ bacteria (based on viable counts performed on suspensions before homogenisation) were mixed with a combination of radiolabelled $(50 \mathrm{nCi} / \mathrm{ml})$ and unlabelled $\left(2.5 \times 10^{-4} \mathrm{M}\right) \mathrm{L}$-histidine. All reaction mixtures were adjusted to a final volume of $1.25 \mathrm{ml}$ with buffer of appropriate $\mathrm{pH}$ and the $\mathrm{pH}$ was checked before incubation. Experiments with lysates from both gramnegative and gram-positive bacteria were performed in the presence of $10^{-5} \mathrm{M}$ pyridoxal phosphate. Additionally, experiments with the gram-negative species were performed in the absence of pyridoxal phosphate. For investigations of the effect of $\mathrm{pH}$ over the range $4 \cdot 0-6 \cdot 0$, sodium citrate phosphate buffer of final molarity $0.2 \mathrm{M}$ was used whereas sodium phosphate buffer $(0.2 \mathrm{M})$ was used in experiments on the effect of $\mathrm{pH}$ over the range $6 \cdot 0-8 \cdot 0$. Negative controls were prepared with the same incubation mixture but with buffer of an appropriate $\mathrm{pH}$ substituted for the bacterial lysate. Positive controls were prepared with commercial preparations of pyruvoyl- and pyridoxal phosphate-dependent HDs from Clostridium perfringens $^{11}$ and Escherichia coli, ${ }^{12}$ (Sigma) respectively, each used at $0.01 \mathrm{unit} / \mathrm{ml}$.

All incubation was in airtight, polypropylene tubes, overnight, in a moist box at $37^{\circ} \mathrm{C}$ and any $\mathrm{CO}_{2}$ generated was absorbed into $200 \mu \mathrm{l}$ of hyamine hydroxide contained in a plastic vial placed in each tube. After incubation, the vials were transferred into $5 \mathrm{ml}$ of scintillant (Beckman Company, High Wycombe) and the radioactive $\mathrm{CO}_{2}\left({ }^{14} \mathrm{CO}_{2}\right)$ fraction was assayed in a Beckman scintillation counter.
${ }^{14} \mathrm{CO}_{2}$ production by bacterial extracts was calculated according to the following formula:

Amount of histidine added $(50 \mathrm{nCi})=$ $200000 \mathrm{cpm}=0.0045 \mu \mathrm{mol} / \mathrm{ml}$.

Therefore, ${ }^{14} \mathrm{CO}_{2}$ produced $(\mu \mathrm{mol} / \mathrm{ml})=$

$$
\frac{\mathrm{cpm}}{200000} \times 0.0045 \text {. }
$$

Histamine in the incubation mixtures was detected by a reversed phase high performance liquid chromatographic technique developed in our laboratory and described previously. ${ }^{13}$

\section{Statistical analysis}

Histamine and ${ }^{14} \mathrm{CO}_{2}$ generation were compared by unpaired Student's $t$ and Mann-Whitney U tests on the logarithmically $\left(\log _{10}\right)$ transformed data. Correlation between histamine and ${ }^{14} \mathrm{CO}_{2}$ generation was assessed by linear regression analysis.

\section{Results}

\section{Correlation between ${ }^{14} \mathrm{CO}_{2}$ release and histamine production}

A highly significant correlation $(\mathrm{p}<0.001, \mathrm{r}=0.95)$ was observed between histamine production and $\mathrm{CO}_{2}$ release by lysates from gram-negative bacteria (fig. 1).

\section{${ }^{14} \mathrm{CO}_{2}$ production by commercial preparations of $H D$}

${ }^{14} \mathrm{CO}_{2}$ production by the commercially available HDs from $C$. perfringens and $E$. coli is shown in fig. 2 . HD from $E$. coli produced significantly $(\mathrm{p}<0.001)$ greater amounts of ${ }^{14} \mathrm{CO}_{2}$ in the presence of pyridoxal phosphate than in the mixture without pyridoxal phosphate or the control mixture. In contrast, HD from $C$. perfringens generated ${ }^{14} \mathrm{CO}_{2}$ in the absence of pyridoxal phosphate in amounts similar to those produced by the $E$. coli-derived enzyme in the presence of the cofactor.

\section{Production of ${ }^{14} \mathrm{CO}_{2}$ by clinical isolates}

The ability of gram-negative bacteria to liberate ${ }^{14} \mathrm{CO}_{2}$ from ${ }^{14} \mathrm{C}$-histidine is shown in fig. 3. Production of $\mathrm{CO}_{2}$ was significantly greater in lysatecontaining tubes supplemented with pyridoxal phosphate than in control tubes $(p<0.001)$. However, generation of $\mathrm{CO}_{2}$ in the absence of pyridoxal phosphate was not significantly different from amounts produced by control mixtures. In contrast, lysates from the gram-positive species, $S$. aureus, $S t r$. pneumoniae, $\alpha$-haemolytic streptococci and coagulasenegative staphylococci did not metabolise histidine. Lysates from these organisms, which were supple- 


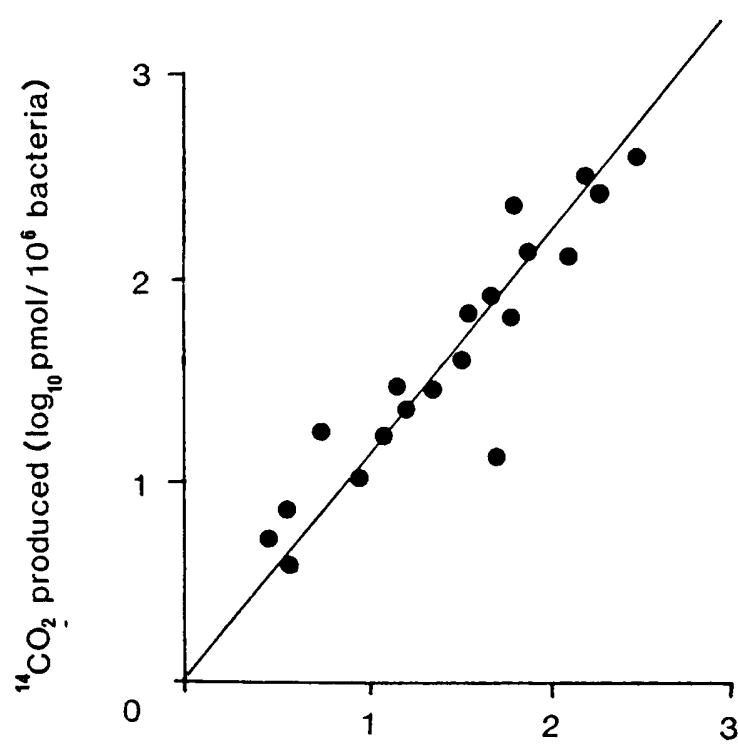

Histamine produced $\left(\log _{10}\right.$ pmol/ $10^{6}$ bacteria)

Fig. 1. Correlation between ${ }^{14} \mathrm{CO}_{2}$ release and histamine production by lysates from 20 gram-negative bacteria.

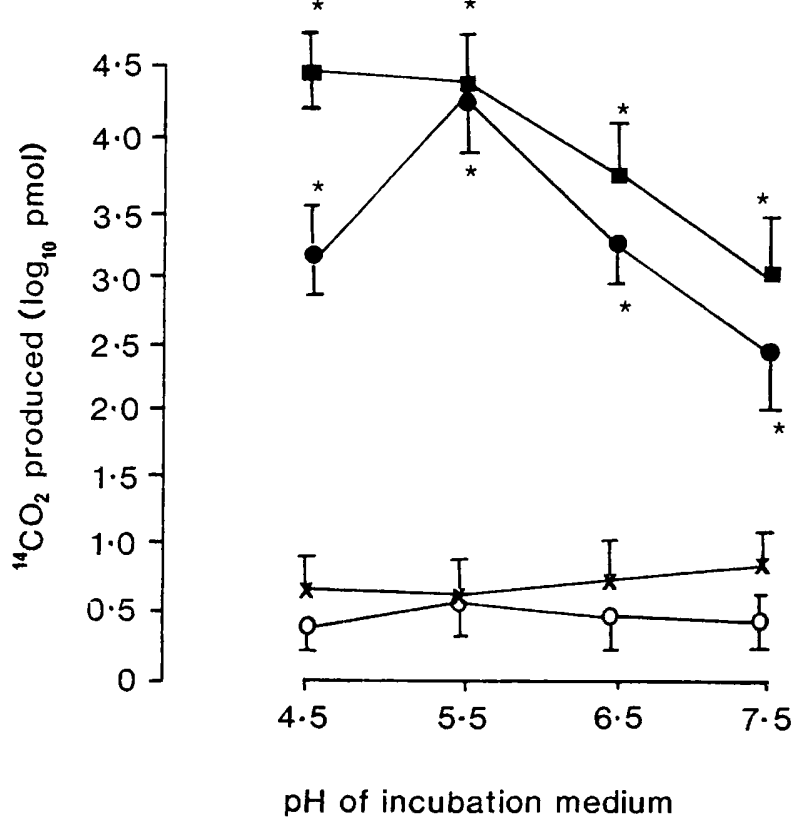

Fig. 2. ${ }^{14} \mathrm{CO}_{2}$ production by commercial preparations of $\mathrm{HD}$ from $E$. coli in the presence $(O)$ or absence $(O)$ of pyridoxal phosphate, and from $C$. perfringens $(\square)$, compared with release of ${ }^{14} \mathrm{CO}_{2}$ from HD-free control mixture $(x)$. Results are expressed as log means and $\operatorname{SEM}(\mathrm{n}=6)(*, \mathrm{p}=<0.01)$.

mented with pyridoxal phosphate, did not produce significantly larger quantities of ${ }^{14} \mathrm{CO}_{2}$ than control mixtures of any $\mathrm{pH}$ value studied (fig. 4).

\section{Discussion}

It has been determined previously that certain gramnegative, but not gram-positive, bacteria that may

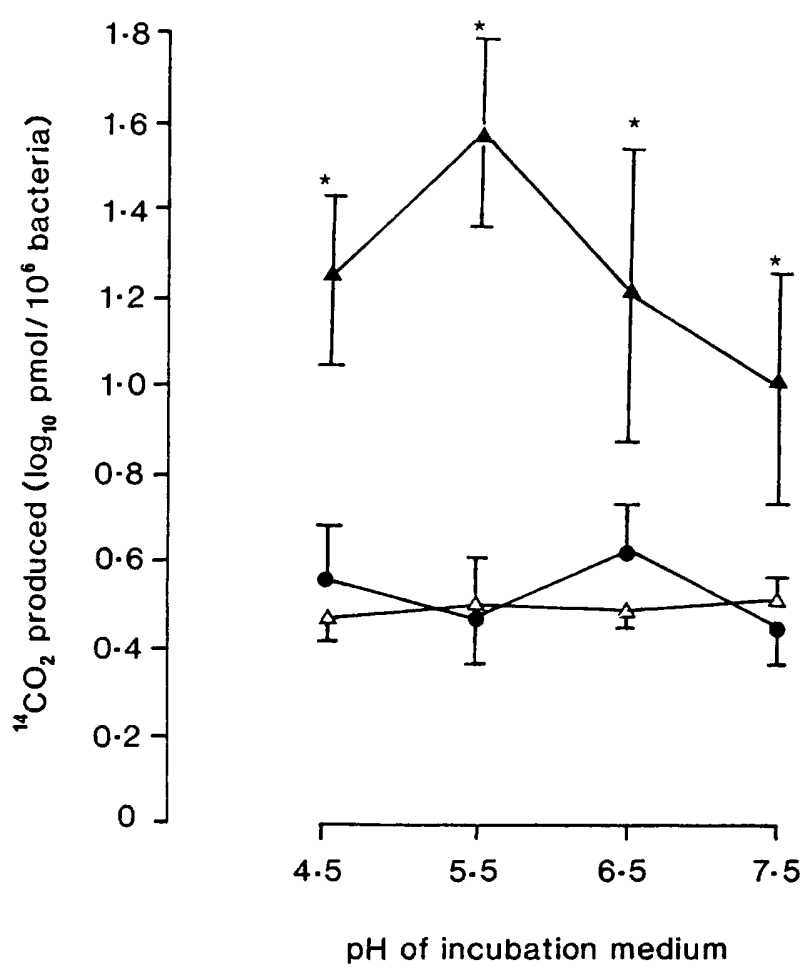

Fig. 3. ${ }^{14} \mathrm{CO}_{2}$ production by lysates from gram-negative bacteria in the presence $(\boldsymbol{\Delta})$ and absence of pyridoxal phosphate $(\triangle)$, compared with release of ${ }^{14} \mathrm{CO}_{2}$ from control mixture $(\bullet)$. Results are expressed as $\log$ means and $\operatorname{SEM}(\mathrm{n}=20)(*, \mathrm{p}=<0.001)$.
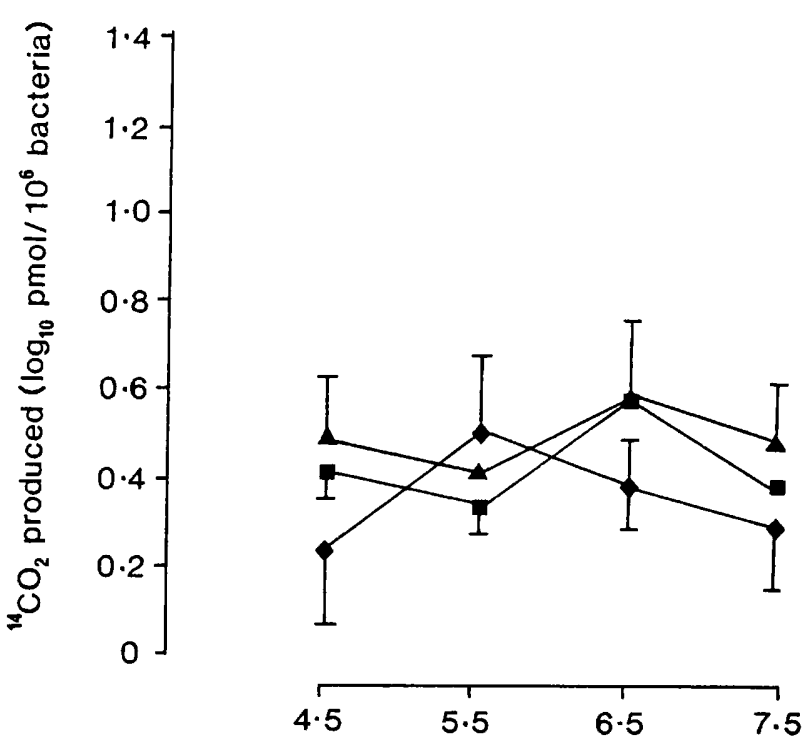

$\mathrm{pH}$ of incubation medium

Fig. 4. ${ }^{14} \mathrm{CO}_{2}$ production by lysates from gram-positive bacteria after sonication $(\boldsymbol{\square})$, lysostaphin treatment of staphylococcal isolates $(\bullet)$ and release of ${ }^{14} \mathrm{CO}_{2}$ by negative control $(\Lambda)(\mathrm{n}=20)$.

colonise the respiratory tracts of patients suffering from chronic bronchitis, cystic fibrosis and pneumonia, are capable of generating histamine in vitro. ${ }^{4}$ The results of the present study demonstrated that gram-negative but not gram-positive species isolated from sputum of similar patients possess HD activity and, therefore, have the capacity to metabolise histidine to $\mathrm{CO}_{2}$ and histamine. Furthermore, the observation that $\mathrm{HD}$ activity in the gram-negative 
organisms was pyridoxal phosphate-dependent over the $\mathrm{pH}$ range examined indicated that their HDs were similar to those previously described among gramnegative species by other workers. ${ }^{5,9}$

Some bacterial amino-acid decarboxylases, including the arginine decarboxylases of species such as $S$. typhimurium and $E$. coli, ${ }^{6}$ have been shown to be capable of metabolising histidine in addition to their natural substrate. In contrast, HDs have been shown to be highly specific for histidine as their substrate. Although we have used crude bacterial lysates that may contain several decarboxylase enzymes that might metabolise histidine to some extent, the results obtained with lysates not supplemented with pyridoxal phosphate indicate that the metabolism of histidine observed in these studies is likely to be due to HDs. The demonstration that a small amount of $\mathrm{CO}_{2}$ was

\section{References}

1. Ienistea C. Bacterial production and destruction of histamine in foods, and food poisoning caused by histamine. Die Nahrung 1971; 15: 109-113.

2. Recsei PA, Snell EE. Pyruvoyl enzymes. Annu Rev Biochem $1984 ; 53: 357-387$

3. Devalia JL, Harmanyeri Y, Cundell DR, Davies RJ, Grady D, Tabaqchali S. Variation in histamine synthesis by Gramnegative and Gram-positive respiratory tract bacteria and the effect of cefaclor. Royal Society of Medicine Services Ltd. International Congress and Symposium Series 1988; 128: 49-55

4. Devalia JL, Grady D, Harmanyeri Y, Tabaqchali S, Davies RJ. Histamine synthesis by respiratory tract microorganisms: a possible role in pathogenicity. J Clin Pathol $1989 ; 42: 516-522$.

5. Guirard BM, Snell EE. Purification and properties of pyridoxal5 -phosphate-dependent histidine decarboxylases from Klebsiella planticola and Enterobacter aerogenes. J Bacteriol 1987; 169 : 3963-3968.

6. Blethen SL, Boeker EA, Snell EE. Arginine decarboxylase from Escherichia coli I. Purification and specificity for substrates and coenzyme. J Biol Chem 1968; 243 : 1671-1677. generated in lysate-free "negative" controls indicated that some spontaneous degradation of histidine must also have occurred under these assay conditions.

In marked contrast to HDs of gram-negative bacteria, several studies have demonstrated that the activity of enzymes from gram-positive bacteria, including L. buchnerii, Lactobacillus $30 \mathrm{a}$ and $C$. perfringens, depends on the presence of a pyruvoyl moiety. ${ }^{2,9,11}$ Our observation that the gram-positive bacteria studied were unable to metabolise histidine, even in the presence of pyridoxal phosphate, could be explained either by the occurrence of inactive forms of $\mathrm{HD}$ in these organisms or by complete absence of the enzyme.

We thank the British Lung Foundation, Eli Lilly, and the Joint Research Board of St Bartholomew's Hospital for financial support.

7. Feldberg RS, Iannitti DA, Cochrane DE. Histidine decarboxylase from rat mast cells. Enhanced recovery in cell-free extracts and isotopic labelling. Biochem $J$ 1988; 249: 297 300 .

8. Tanase S, Guirard BM, Snell EE. Purification and properties of a pyridoxal-5'-phosphate-dependent histidine decarboxylase from Morganella morganii AM-15. J Biol Chem $1985 ; 260: 6738-6746$.

9. Vaaler GL, Brasch MA, Snell EE. Pyridoxal 5'-phosphatedependent histidine decarboxylase. Nucleotide sequence of the hdc gene and corresponding amino acid sequence. $J$ Biol Chem 1986; 261 : 11010-11014

10. Beaven MA, Horáková Z, Severs WB. Bacterial histidine decarboxylase in rat stomach. Eur J Pharmacol 1970; 11: 233-240.

11. Recsei PA, Moore WM, Snell EE. Pyruvoyl-dependent histidine decarboxylases from Clostridium perfringens and Lactobacillus buchneri. J Biol Chem 1983; 258: 439-444.

12. Lawson A, Quinn AG. Studies on amino acid decarboxylases in Escherichia coli. Biochem $J$ 1967; 105: 483-490.

13. Devalia JL, Sheinman BD, Davies RJ. Highly sensitive highperformance liquid chromatographic technique for the simultaneous measurement of histamine, 1-methyl-histamine and other biogenic amines. J Chromatogr $1985 ; 343$ : $407-412$. 